\title{
Thāj through the course of its history and the Saudi work there
}

\author{
Marwan Ghazi Shuaib \\ King Abdulaziz University
}

\begin{abstract}
Thāj is considered one of the most important ancient sites in the north-east of the Arabian Peninsula. However, information gained from research at the site raised many questions, which require careful consideration before reaching correct answers. For example, what are scholars able to say regarding the inscriptions and the coins which have been found in Thāj? What are new findings have been achieved from the excavations in Thāj? What is the connection between Thāj and the lost Arabian city of Gerrha? This study seeks answers to these questions and carefully reviews the discussions published in older studies.
\end{abstract}

Keywords: Thāj - Gerrha - Ancient History - Archaeology - Excavation - Hasaean inscriptions.

Thāj is an important archaeological site in the north-east of the Arabian Peninsula. It is located at $26^{\circ}$ and $50^{\circ}$ north and $48^{\circ}$ and $45^{\circ}$ east, i.e. some $95 \mathrm{~km}$. from the coast of the Arabian Gulf at al- Jubayl and $150 \mathrm{~km}$. from Dhahran. It is also located $5 \mathrm{~km}$. from the old trade road known as Darb al-Kunhuri (see fig. no. 1). This archaeological site was discovered by a group of local nomads, who reported it to the British authorities in Kuwait in 1908 (Mandaville 1963: 10; Gazdar 1984: 49).

Thāj was mentioned in Islamic sources: the references to Thāj in Islamic works were gathered more than fifty years ago by Mandaville (1963: 172) and Mandaville's work was rehearsed and summarized with some valuable additional material in 1990 by Potts (1990: 34). A summary of previous work is presented below with some clarification.

The earliest mention of Thāj comes in an ode of the pre-Islamic poet 'Amr ibn Kulthum, who mentioned Thāj as a watering place in the words, 'the flowing wells of Thāj invite the wild she-asses' (Muhammed ibn Ya'lā al-Ḍabbī 1963:307). During the late sixth century $\mathrm{AD}$ Thāj is again mentioned 
when Rāshid ibn Shihāb al-Yashkurī says that he built his castle in Thāj. The statement of Rāshid ibn Shihāb suggested that Thāj was an important place, or at least sufficiently well known in the Arabian Peninsula during pre-Islamic times to persuade him to build his castle in this area. Rāshid ibn Shihab alYashkurī says:

I have built in Thāj a castle of stone, to make of it a refuge in spite of them who would revile me. Proud and high it rises; [even] the birds slip down before it; built in it are some of the blocks quarried for it by Iram. He who seeks safety from death takes refuge in it, and to it repairs he who would exchange utter poverty for plenty (Muhammed ibn Ya'lā al-Ḍabbī 1963: 309, trans. Mandaville 1963: 16).

There is no other evidence to the effect that this castle either was or was not built by Rāshid, although, as Mandaville noted, the construction of the castle might have been a symbol of tribal influence (Mandaville 1963: 16). However, the poem does suggest that Thāj was an antique place for the tribe of Bakr ibn Wā'il before AD 600 (Mandaville 1963: 17).

During the Umayyad period Dhū alRummah (ca. 696-ca. 735) mentioned Thāj when he said: 'He turned his riding-camel towards Thāj and then headed with her for al'Anayn' (al-Bakri 1945: 333). It is believed that al-Jubayl is the modern name of al'Anayn (Mandaville 1963: 18; Potts 1990: 34). We can understand from his poem that Thāj was still recognized as a functioning city during that period. During the same period
al-Farazdaq spoke of ' ...cracks with bottoms so deep, as though they were Rakīyat Luqmān, that is like a dahl'. In his recension of Naqā'id Jarīr wa'l-Farazdaq Abu 'Ubaydah stated that 'Rakiyat Luqmān is at Thāj' (Naqā'id, I [1905]: 130). Thāj was mentioned again in 691 when 'Abd al-Mālik ibn Marwān fought Mālik ibn Misma'. After that battle Mālik ibn Misma' escaped to Thāj to join the leader of al-Khārijit Najdah alHarūrī, who gave Mālik one hundred camels on his way to Bahrain (Naqā'iḍ, II [1905]: 1092).

Thāj is also mentioned in Arab geographical works. Thus, during the mid tenth century al-Hamdān̄ mentioned Thāj as a watering place belonging to Tamīm. Writing in the eleventh century AD, al-Bakrī (I, 1945: 333) mentioned Thāj as a 'village in al-Bahrayn'. In Mu 'jam albuldān (AD 1229) Yāqūt (I, 1955: 913 f.) mentioned Thāj as 'a spring several nights' journey from al-Bahrayn', adding that Thāj was a village in al-Bahrayn. Mandaville (1963: 19) summarized his discussion about Thāj in Arabic sources by saying that during the early Islamic period Thāj was connected with Yamāmah and played a minor role as a caravan city supplying water for travellers along the trade road.

It has been suggested that Thāj is to be identified with Phigeia, which appears in the map of Ptolemy (see Claudius Ptolemaeus 2011: fourth map of Asia) during the second century AD (Mandaville 1963: 19). This theory is supported by two observations: first is that Phigeia is located near or in the same place as the current place known as Thāj; and, 
second, that people from al-Qatif replace the consonant th with $f$ in their dialect (e.g., faläfah for thalāthah, 'three') (Mandaville 1963: 19).

During the eighteenth century $\mathrm{AD}$ the Ottoman Imperial government ordered 'Ali Pasha of Baghdad to halt the expansionary policy of Al Sa'ud towards the eastern part of the Arabian Peninsula (Louis 1810: 53-58). The commander of the Saudi military, Prince Sa'ud ibn 'Abd al-Aziz (1765-1814), met 'Ali Pasha in a bloodless confrontation in Thāj. As a result of this campaign the name of the place called Thāj found its way into European geographical information in 1823 when Mengin (1823: 608) mentioned Thāj as a village in Najd.

The second mention of Thāj by European writers was made by L. Pelly during his visit to Riyadh in 1865. Thāj was described to Pelly by local people as a place with many traceable walls lying three days' march from Qatif. Local people informed Pelly that Thāj was a main town of al-Ahsa, built of white stone (Pelly 1865: 24). Lorimer, who obtained his information about Thāj from the report of Pelly, succeeded in describing the site of Thāj in depth. He was able to report the area of Thāj as about 1 mile in length by $1 / 2$ mile in breadth and he also noted some inscriptions found on stones in Thāj (Lorimer 1908: 1234, 1231).

However, the first European to actually visit Thāj was Capt. W.H. Shakespeare, the British political agent in Kuwait between 1909 and 1915. Shakespeare discovered two south Arabian grave inscriptions, which were the first south Arabian inscriptions to have been found in north Arabia. These inscriptions have been taken as evidence of the connection between south and north Arabia. In addition, another south Arabian inscription was found by H.R. Dickson, the British political agent in Kuwait during the mid twentieth century, with the co-operation of local nomads. This text seems to have been inscribed on a grave monument and was published by Ryckmans in $1937^{2}$. Dickson and his wife visited Thāj in 1942 and in 1948 published some valuable notes about it (Mandaville 1963: 10). In the following section we will discuss inscriptions from the north-east of the Arabian Peninsula.

At Thāj today, there is a group of ruined buildings constructed of black mud bricks. Mandaville (1963: 10) described its population in his time as consisting of nomads from the 'Awazim tribe, who used to move between Kuwait and lands to the north of Riyadh, and sojourned in Thāj during the summer because the location offered plenty of water. Indeed, Thāj still has many ancient palm-groves, indicating that it has long been a rich oasis. The site of Thāj contains signs of habitation during pre-Islamic times. Moreover, Thāj has more than twenty old wells, twelve of which still provide water. In Thāj additionally has been found a considerable amount of baked clay objects, some of which are shaped in the form of camels or human statuettes (Mandaville 1963: 12 f.).

The early visitors to Thāj found important numismatic evidence that shows the history of Thāj going back to the Hellenistic era (300 BC- AD 300). Two coins from Thāj have 
frequently been reported in different sources (Altheim \& Stiehl 1964: 95 \& fig. 38; Robin 1974: 87, 89). They bear the portrait of Zeus on one side and on the other side a head of Heracles. In addition, one of the coins has an inscription in South Arabian script which could be read as Abyata, probably the name of the king who minted this coin (see fig. no. 2). The other coin has an Aramaic text, but it is difficult to read. However, other examples of this type help to reconstruct the text, which contains the name of a king called Abi'el (Potts 1983: 92).

These coins raise a number of problems such as their dating, their distribution, and their place of mintage, all of which have been discussed by Mørkholm (1960: 190) and Robin (1974: 87ff.). However, these two scholars are not totally agreed about the precise information which may be obtained from the coins (Potts 1983: 93). We should note that coins bearing the name Abyata have also been found outside Thāj, but they have various dates, like those found in Jordan which have been dated to around $200 \mathrm{BC}$ (Cox, 1966: 39). In addition, some of Abyata's coins have been found at Failaka and their dates go back to the late third century BC. Scholars have suggested that the coins from Failaka might have been minted in the eastern part of the Arabian Peninsula (Mørkholm 1960: 206 \& fig. 5; Potts 1983: 93).

Coins bearing the name of the king Abi'el have been found both at Thāj and as far away as Susa ${ }^{3}$. Two coins out of 97 which have been found in the latter place were dated to 140 BC (Le Rider 1965: 202). In addition, in
Bahrain 77 out of 292 coins in city $\mathrm{V}^{4}$ (see Mørkholm 1972: 197-199 \& fig. 5) have been dated to $130 \mathrm{BC}$ (Potts 1983: 93).

The place where these coins were minted is a controversial issue, since Mørkholm and Robin are not totally agreed on the matter (Mørkholm 1960: 199; Robin 1974: 112; Potts 1983: 93). The name of king Haritat also appears on coins which are closely related to coins of Alexander the great (356323 BC). Robin (1974: 112) suggested that all the above kings (Abyata, Abi'el, and Haritat) were rulers of $\mathrm{Hagar}^{5}$, whose regnal eras were respectively $220-200,180-160$, and $150-140$ BC.

As the above discussion demonstrates, Thāj has been attracting the attention of western scholars for a long time and as a result of their work Thāj has started to receive considerable interest from Saudi scholars. In 1976 the Department of Antiquities and Museums of Saudi Arabia's Ministry of Education sponsored a plan to carry out an archaeological reconnaissance of the whole Kingdom of Saudi Arabia. This survey has covered the al-Jawf/Wādi al-Sirḥān area and has included the eastern part of the Arabian Peninsula (see al-Atlal I, 1397/1977, 21). The Arabian-American Oil Company (ARAMCO) has also demonstrated an interest in the ancient civilizations and cultures of the Arabian Peninsula and has participated significantly in this project (Robert 1977: 23).

This work was the first phase of a comprehensive archaeological survey program of the Arabian Peninsula and is viewed as the completion of the Danish 
mission in the eastern part of Saudi Arabia (see Bibby: 1973). In 1968 this Danish team carried out excavations under the supervision of T.G. Bibby in the eastern part of Saudi Arabia, which included an area of about 50 square meters in Thāj. The report of this excavation referred to Thāj as an important ancient site. The expedition found in Thāj two pieces of pottery from the Seleucid period and some arrowheads from the Bronze Age (Bibby 1973: 43). The report of this archeological reconnaissance sheds light on the efforts of early western scholars such as Lorimer (1908) and also records the discovery of some mud-walled forts (Robert 1977: 2324).

The report reveals that the settlement of the eastern part of the Arabian Peninsula may be divided into four phases. The first phase was when the 'Ubayd civilization appeared in Mesopotamia and some places in the eastern part of the Arabian Peninsula, which may be dated to the fifth millennium BC. The second level of settlement was during the third millennium BC. Which this region witnessed active trade with Mesopotamia. During the third phase we find evidences of commercial relations across the Indian Ocean and these relations continued during Hellenistic and Seleucid times (312-63 BC). The fourth phase witnessed most of the known events during the time immediately prior to the rise of Islam (Robert 1977: 25 f.).

In 1977 a Harvard archaeological team cooperated with a Saudi team from the Department of Antiquities and Museums to carry out a comprehensive archaeological survey and to write a report on the second phase of the eastern province of Saudi Arabia. Excavations were completed under this cooperative endeavour in several areas in Saudi Arabia, including the eastern part, namely in Nariya, Abqayq, and near Dhahran (Potts 1978: 9). The report of this expedition reveals that this area had trade relations with regions beyond the Arabian Peninsula during different times, including the Hellenistic, Parthian (247 BC - AD 224), and Sassanian (AD 224-651) eras. In addition, it was revealed that Thāj flourished in Hellenistic times (215-208 BC), coincident with the prospering of other parts in the south and east of the Arabian Peninsula $^{6}$ (Potts 1978: 10).

In 1983 an archaeological team which included Muhammad Gazdar from Saudi Arabia, and Daniel Potts and A. Livingstone from the UK published a report about the excavations carried out during that year, in which it was emphasized that Thāj was an important archaeological site (Gazdar 1984: 49, 55). In addition, the team found many graveyards around Thāj, most of them similar to those distributed in many places across the eastern part of the Arabian Peninsula. Some tombstones were also found during this excavation, all of them bearing fragmentary Hasaean inscriptions (see fig. no. 3).

The focus of this excavation, conducted over 85 days, was concentrated within the residential part of the oasis inside the wall of the city as well as in three different places outside the wall (Gazdar 1984: 49). The expedition found many small animal models, one of them resembling a camel (see fig. no. 4), made from locally sourced red clay and painted white. 36 coins were also found at 
Thāj during this excavation, some of them bearing fragmentary south Arabian inscriptions. Unfortunately, only a few of them could be read. On the upper part of coin no. 18 from right to left can be read $t b$ [?] $x x$ $y$. In the lower part and in the same script from right to left we read $t h^{c} l d y d n$ [?] (Gazdar 1984: 77; see fig. no. 5).

This excavation delivered a long report about the finds at Thāj, which is difficult to summarize here. However, the excavations during this season demonstrated that Thāj was an active city during ancient times and that its settlement may be divided into five stages. In addition, the report pointed to cultural communication between Thāj and south Arabia, reflected especially in the form of the writing, since most of the discovered tombstones bear inscriptions in S. Arabian script. Moreover, the pottery from Thāj shows evidence of a connection between Thāj and Hellenistic civilization. The report also suggests that settlement at Thāj might have extended from $300 \mathrm{BC}$ to $\mathrm{AD} 300$ (Gazdar 1984: 83). All this evidence points to the fact that Thāj played a significant role as a caravan city during ancient times.

In 1984 the Department of Antiquities and Museums conducted further excavations at some selected places both inside and outside the walls of Thāj. This campaign found some bronze coins, pottery and other vessels, Hasaean gravestones, and several others small items. The report of this excavation again emphasized that the settlement in Thāj could be divided into five phases and that the city was affected by Hellenistic civilization (Eskoubi 1985: 41).
Abdulhameed al-Hashash and his companions carried out a series of excavations at Thāj between 2000 and 2006 (see al-Atlal XVII, 2002: 17-27; XVII, 2005: 19-21; \& XIX, 2006: 15-19). In 2000 excavations were made in three different places, the first at the mound of al-Zayr, the second about $200 \mathrm{~m}$. to the north of that mound, and the third in the south-east of alZayr (al- Hashash 2005: 35).

The reports of these excavations reveal that the marsh of Thāj and the other marshes around it were rich sources of salt, suggesting that Thāj managed to flourish as an exporter of this commodity (al-Hashash 2005: 45). In addition, carbon-14 examinations at Thāj demonstrate that settlement there may have extended back before 600 BC (al-Hashash 2006: 19).

The Saudi Commission for Tourism and Antiquities (SCTA) is working everywhere in Saudi Arabia to discover, excavate, and record archeological sites. Ali al-Ghabban, the vice president of SCTA, recently suggested that the ancient site of Thāj could have served as the seaport of the Jahra kingdom, which controlled the eastern part of the Arabian Peninsula during the third century BC. Al-Ghabban noted that the exact date of this site cannot be determined before final results are to hand (al-Ghabban 2011).

\section{Thāj and the problem of the location of Gerrha, or Gerra}

Strabo (XVI, 3: 3) described a city called Gerrha and its inhabitants in the north-east of the Arabian Peninsula, which led to the 
discussion in the preceding section. But the location of this city is also a controversial issue and opinions in sitting it have differed. Musil proposed that the tribe of Gerrha probably spread over the eastern part of the Arabian Peninsula and as far north as the Euphrates, adding that the Agraei tribe might have controlled the trade roads in the eastern part of the Arabian Peninsula up to the south of Petra. He stated that Gerrha, located to the south-east of Petra, was probably in the Middle Babylonian period (943-729 BC) the place known as Hagar, located at al-Hufuf, namely in Thāj (Musil 1927: 498).

In his discussion of the location of Gerrha, Robin (1974: 102-111) concluded that this city could have been the oasis of Dumat alJandal in the northern part of the Arabian Peninsula, because coins of Hagar have been found at this site. In contrast, von Wissman (1975: 35, 43) was of the opinion that the Hagarites should be located in the eastern part of the Arabian Peninsula in the region of alHasa, which was known during the Middle Babylonian period as Hajjar, A-ga-rum in Kassite inscriptions from Bahrain, Agraei in the writings of Pliny, Ptolemy, and Strabo.

Mørkholm (1973: 200) suggested that the eastern part of the Arabian Peninsula, particularly Bahrain, was the proper place for the lost city because the Hellenistic coins minted in Bahrain and Failaka gave a clue that the lost city of Gerrha flourished in that area. In addition, as mentioned above in 1977 the Harvard archaeological team with the Saudi team excavated in Nariya, Abqayq and near Dhahran searching for the proper location for Gerrha. But this fieldwork like other studies about Gerrha failed to find the precise place for this lost city (Potts 1978: 10).

Groom (1982: 107) concluded his discussion about the lost city of Gerrha by observing that the most likely location of Gerrha should be sought in the Hasa oasis or not far away from al-Hufuf city. In fact, the widespread distribution of the Agraei tribe, mentioned by Strabo (16, 4: 2), makes it difficult to determine the location of their fortress or their capital city (Potts 1983: 93).

However, the size of Thāj and the many castles which have been found in this town and the varieties of remains, the Hasaean inscriptions and bronze coins all serve as evidence leading many scholars to believe that Thāj played a significant role during ancient times (Dickson 1948; Mandaville 1963; Lapp 1963; Parr 1964; Eskoubi 1985: 41). Therefore Thāj might well be the most likely location for the lost city of Gerrha, as was suggested by Musil (1927: 498).

\section{Inscriptions from the north-east of the Arabian Peninsula}

Since opinions differ regarding the scripts used in eastern Arabian inscriptions, in this section we will discuss the opinions previously expressed. A few inscriptions have been found at Thāj, which probably date back to different periods, such as those of Uruk $^{7}$, and Ur ${ }^{8}$. Capt. W.H. Shakespeare, previously noted as the first European to have visited Thāj, found an inscription on a tomb near 'Ayn Jawan which could be a Chaldean text. In addition, some inscriptions in South Arabian script have been found in al-Hufuf 
which have been identified as Chaldean (Potts 1983: 87).

Others believe that they are Proto-Arabic or Old Arabic (Potts 1983: 87). Eph'al (1974: 109) noted that most of the other texts which Albright (1952: 39-45) called Chaldean were found in regions into which Arabs penetrated, not only in Bit-iakin, so it seems reasonable to attribute them to Arabs rather than to Chaldeans. In addition, Eph'al (1974: 113) believed that all the texts found in Thāj should be classed as Proto-Arabic, 'as they were called at the time of their first discovery.' In contrast, von Wissmann (1975: 29, n. 1) called them Hasaean inscriptions, while, F.V. Winnett (1946: 5-7) suggested that seals found in Thāj might have Dedanite texts and that they were closely similar to the inscriptions in Jabal Ghunaym near Tayma.

However, the above discussion of the older scholars about the origins of the inscriptions found in Thāj can neither establish nor disprove the possible origin of the Chaldeans either in the Arabian Peninsula or their migration in the opposite direction. In this connection, Eph'al (1974: 109, n. 12) stated that these inscriptions were similar to the south Arabic texts found in Babylonia before the appearance of the Chaldeans. Winnett (1980: 138) noted that the inscriptions from the north-east of the Arabian Peninsula did not correspond with Sabaean or Himyaritic, but stood alone in their type. Winnett himself called them Hasaean because they had been found in al-Hasa region and this theory found agreement with R. LeBaron Bowen and A. Jamme (Potts 1983: 89). Hamad bin Seray
(1991: 13) stated that while the inhabitants of north-east Arabia were Arabs, they used to write using Sabaean characters, as Hasaean inscriptions from the area prove.

\section{The Hasaean inscriptions}

The first person to refer to the texts from north-eastern Arabia as Hasaean inscriptions was R. LeBaron Bowen (Potts 1983: 89). Bowen was followed by A. Jamme, who published 17 Hasaean texts (Jamme 1966: 66). Winnett (1946: 6) had already noticed the peculiarity of these texts when he proposed that they 'should not be classed as Sabaean or Himyaritic but should be put in a class by themselves. ${ }^{10}$

Jamme (1966: 67) noted the influence of Sabaean, Minaean, and Nabataean on Hasaean inscriptions, while Altheim and Stiehl preferred to see in them the influence of eastern Aramaic rather than of Nabataean ${ }^{11}$ (Potts 1983: 89). C. Robin discussed in depth the linguistic issues involved in 27 Hasaean inscriptions, but his conclusion was presented without any suggestion as to the precise dialect they represented. He (1974: 114) added that there was a kind of similarity between the linguistic features of Hasaean inscriptions and a few texts from south Arabia. von Wissman (1979: 34) considered that the northern Minaean texts and Hasaean texts could be descended from the south Arabian inscriptions. A.F.L. Beeston (1979: 17) suggested that Hasaean inscriptions could be classified as a unified linguistic group, while Müller (1978:155) believed that the Hasaean inscriptions proved to be early north 
Arabian inscriptions which were written in south Arabian script.

The dating of Hasaean texts is an additional matter of controversy. Winnett (1946: 5) suggested a very late date, between the fifth and sixth centuries AD (Winnett 1946: 5), while in contrast Jamme (1966: 66) proposed the fourth century BC. Robin (1974: 117) suggested a date between the fourth and the second centuries $\mathrm{BC}$ and von Wissman (1975: 30) proposed the Seleucid period as a suitable date for the Hasaean inscriptions. Overall, as Potts (1983: 89) stated, the utilization of Hasaean texts is still of limited value, because most of them are grave inscriptions which contain personal names or clan names without any historical information.
To conclude, it is clear that Thāj played a significant role as a trading city during the course of its history, in almost exact parallel with the role we know to have been played by Gerrha. Thāj occupied a strategic location on Darb al-Kunhuri, not far from the sea. It is mentioned in pre-Islamic poetry and in Islamic sources as a destination for travelers in the north-east of the Arabian Peninsula. In addition, the inscriptions and the coins which have been found in Thāj testify to the importance it once enjoyed. Moreover, the excavations carried out at the site of Thāj show that it was an ancient site dating back perhaps to the fifth millennium BC. In fact, if one were to study the history of the oases in the north-east of the Arabian Peninsula in order to determine the most likely site of the lost city of Gerrha, one would have to nominate Thāj as the most fitting location.

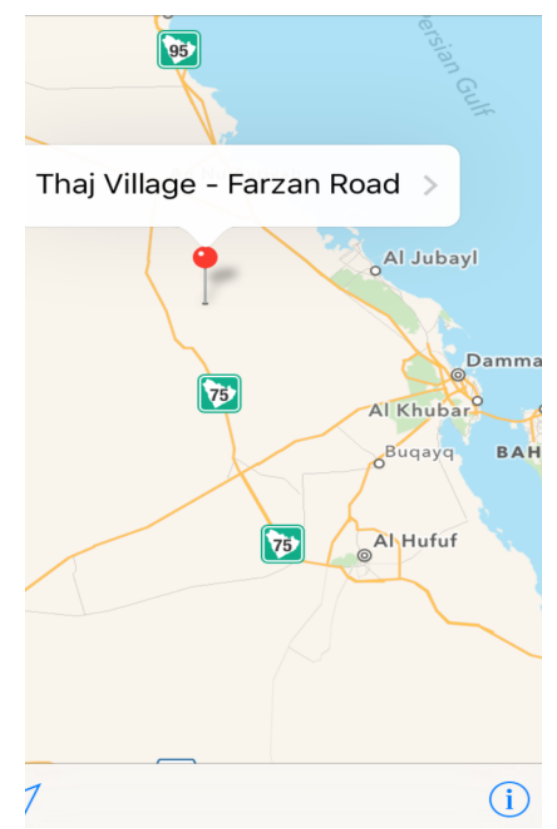

Figure no. 1: the location of Thāj 
Marwan Ghazi Shuaib

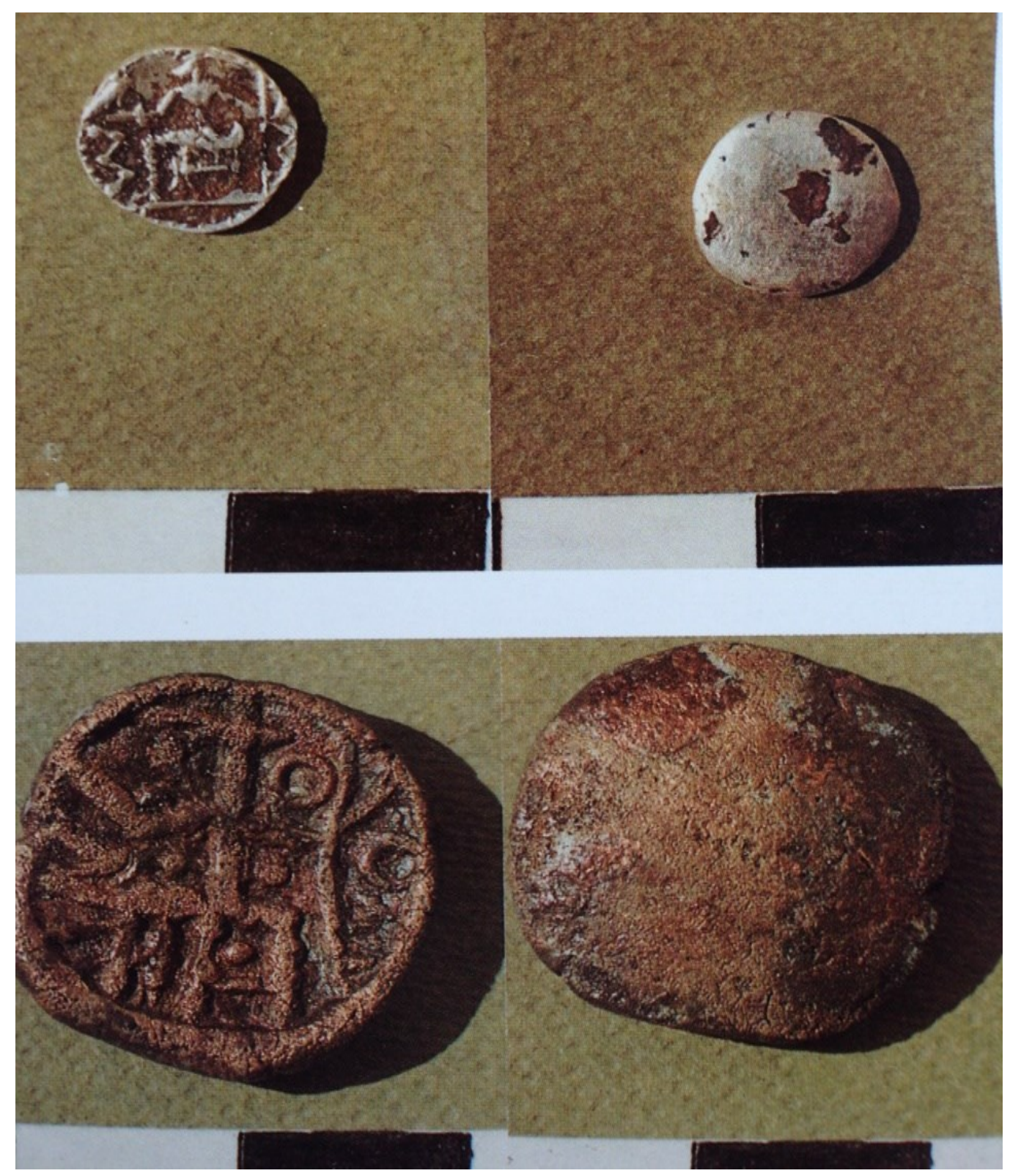

Figure no. 2: coin from Thāj (Gazdar 1984: plate no. 84 B) 


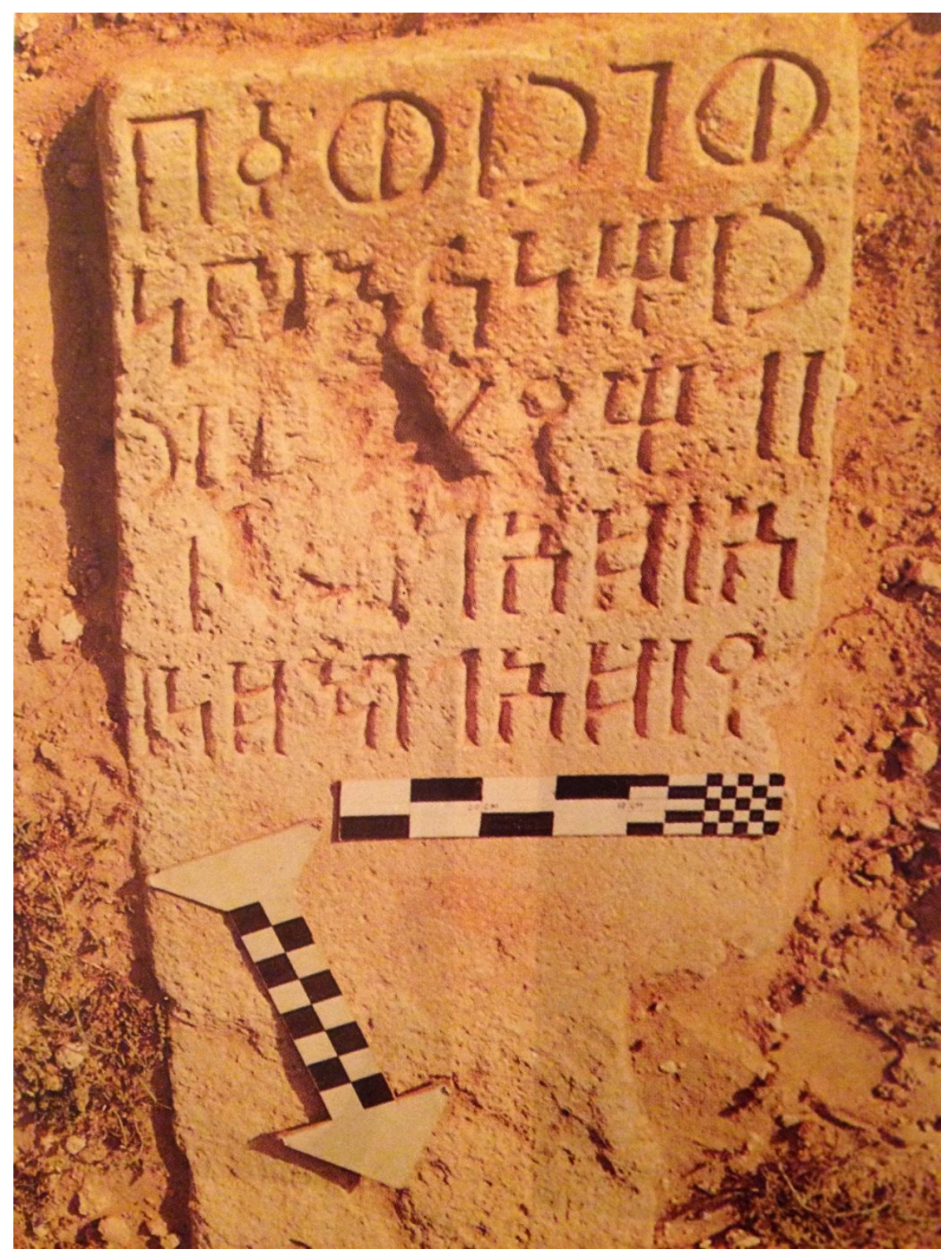

Figure no. 3: a tombstone from Thāj

(Gazdar 1984: plate no. 86 B) 


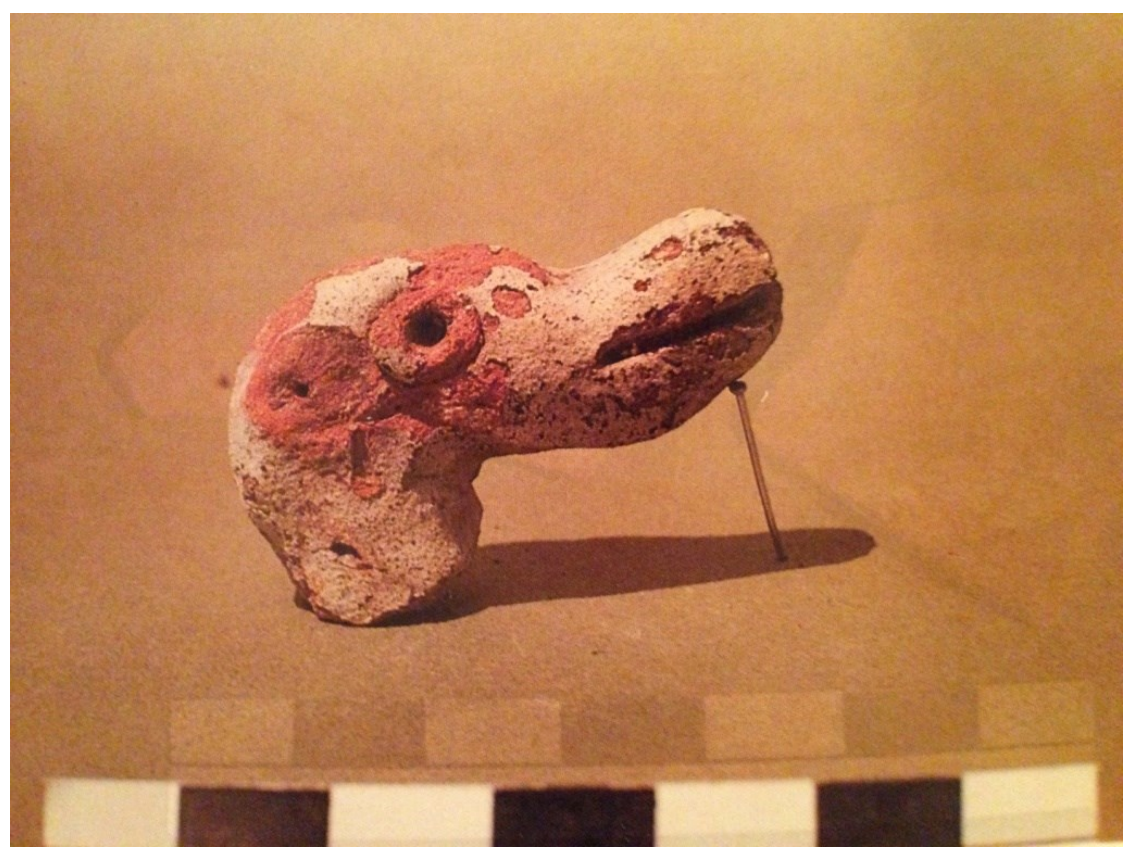

Figure no. 4: an animal figure from Thāj (Gazdar 1984: plate no. 80 B)

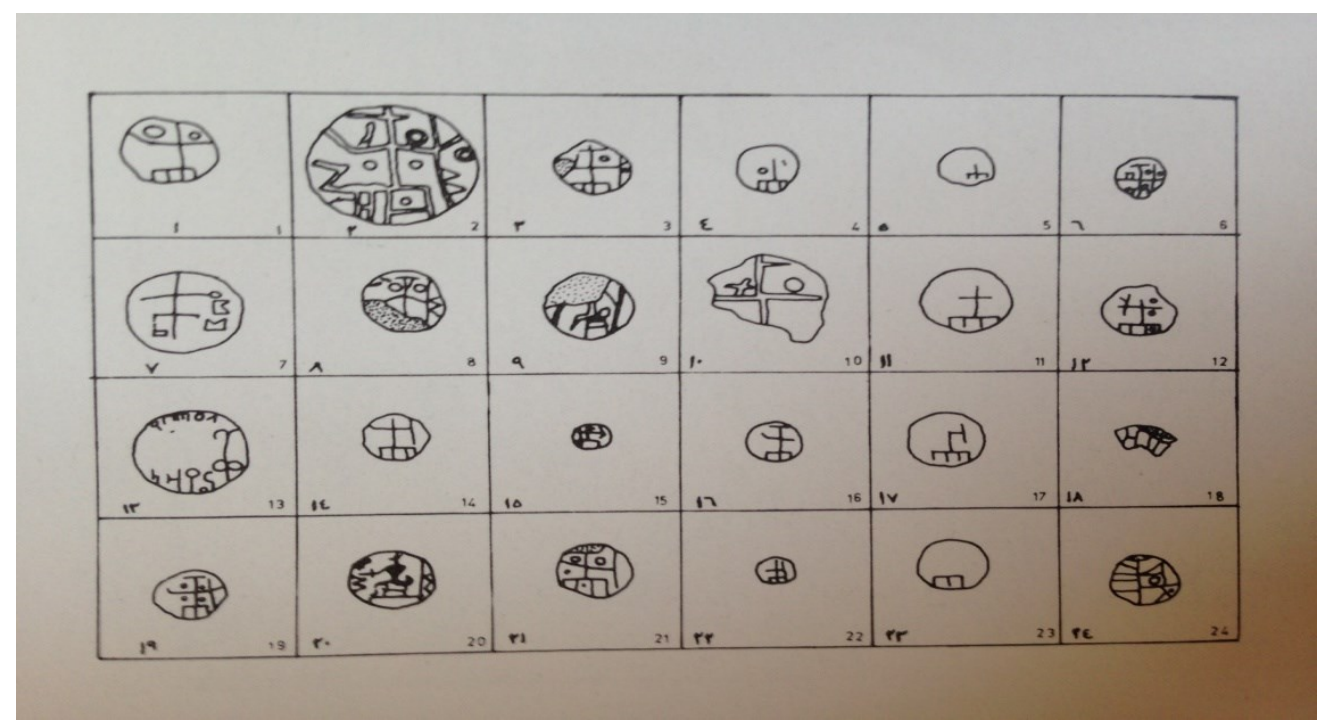

Figure no. 5: coins bearing south Arabian inscriptions (Gazdar 1984: plate no. 75) 


\section{Footnotes}

1- In Mandaville 1963:16 the name of this Jāhiliyya poet is slightly wrong (also in Potts 1990: 34). Mandaville gave the name Qays as father of Rāshid. Rāshid ibn Shihāb alYashkurī recited the ode before Qays ibn Mas'ūd ibn Qays (see Muhammed ibn Ya'lā al-Ḍabbī 1963: 307). For this text see (Gazdar, 88):

2- wgr/wqbr/Grave and tomb of $\mathrm{r} /$ 'ws/hn 'Aws-han-ilat, 'it/bn/sl son of sacd 'cd/bn/gsl son of Ghassanat nt/d'l/yd he of the clan yadcab $\mathrm{Cb} / \mathrm{d}^{\prime} \mathrm{l} / \mathrm{s} 1$ of the tribe wbd shawdhab.

3- Susa is an ancient city which located in southwest Iran not far from southern Mesopotamia (Kuhrt 1995: 11). However, the unique location of this city gave its chance to play a significant role during the ancient history of Mesopotamian empires (for more details see Delaporte 1925: 19).

4- It is the zone of Qal'at al-Bahrain (see Rachel 2011: 38).

5- Hagar is the name of an ancient tribe which was found in sources from Akkadian time until early Islamic time as people occupied eastern part of Arabian Peninsula. It is believed that this tribe could be controlled the Arabs trade during the pre-Islamic time from north east of Arabian Peninsula up to the west of the Euphrates (for more details see Musil 1927: 498; Potts 1983: 93-94).
6- Studying of the eastern part of the Arabian Peninsula leads to discussion of the issue of Gerrha.

7- It dates fourth millennium BC (Kuhrt 1995: 23)

8- It dates last century of third millennium BC (Kuhrt 1995: 58).

9- Musil (1927: 542, 544, 546) called them Arabic inscriptions.

10- These texts have been studied in detail by many scholars, all of whom concluded in accepting Winnett's theory. See von Wissman 1975: 32-35; Müller 1978: 149-157; Beeston 1979: 17-18.

11- As an example of Hasaean inscriptions which have been published by Jamme: wgr/wqbr/ Grave and tomb of s2 mt'/w'h Shamta' and her sister th/6ts2c?/ Batsha ca' bnt/'s1lm daughter of 'Aslam bn/[... son of [... (Jamme 1966: 72 text no. ja 1046; Gazdar 1984: 87 text no. 1).

\section{Bibliography}

Adams, R.McC. et al. (1977), 'Saudi Arabian archaeological reconnaissance,

1976', al-Atlal, XX, 21-40

Albright, W.F. (1952), 'The Chaldaean inscriptions in proto-Arabic script', Bulletin of the American Schools of Oriental Research, CXXVIII, 39-45 Altheim, F. \& Stiehl, R. (1964), Die Araber in der alten Welt, vol. I, (Berlin: Walter de Gruyter) alBakrī, A. 'U. b. 'A. A. b. 'A. 'A. (1945), Mu'jam mā ista 'jam min asmā' al- bilād wa-al-mawādì, vol. I, (Beirut: Dār al-Kitāb al-'Arabī) Beeston, A.F. (1979), 'The Hasaean tombstone J 1052', Journal of the Ancient Near Eastern Society of Columbia University, XI, 17-18 
Bevan, A.A. (1905), Kitāb an-Naqā'ị̣ (Leiden, 1905)

Bibby, T.G. \& Kapel, H. (1973), Preliminary survey in East Arabia 1968. (Reports of the Danish Archeological Expedition to the Arabian Gulf, 2; Jutland Archaeological Society publications, 12.) (Copenhagen: Gyldendal)

Boucharlat, R. \& Salles, J.F. (1981), 'The history and archaeology of the Gulf from the fifth century BC to the seventh century $\mathrm{AD}$ : a review of the evidence', Proceedings of the Seminar for Arabian Studies, XI, 65-94

Brinkman, J.A. (1968), A political history of postKassite Babylonia (1158-722 BC). (Analecta orientalia, vol. 43.) (Roma: Pontificium Institutum Biblicum)

Burrows, E. (1927), 'A new kind of old Arabic writing from Ur', Journal of the Royal Asiatic Society of Great Britain and Ireland, no. 4, 795-806

Cornwall, P.B. \& Goetze, A. (1952), 'Two letters from Dilmun', Journal of cuneiform studies, VI, 137-145

Corancez, L.A.O. de (2006), Tārīkh al-Wahhābīyīn mundhu nash'atihim hattā 'ām 1809 m [originally published as Histoire des Wahabis; depuis leur origine jusqu'à la fin de 1809 (Paris, 1810)], trans. into Arabic by M.K. al-Biqā'ī \& I.Y. al-Balawī (Riyadh: Dārat al-Malik 'Abd al-'Azīz)

Claudius Ptolemaeus (2011), The geography, trans. E.L. Stevenson et al. (New York: Cossimoclassics)

Cox, D.H. (1966), 'Gordion hoards III, IV, V and VII', Museum notes (American Numismatic Society), XII, 19-55

Delaporte, L. (1925), Mesopotamia: the Babylonian and Assyrian civilization (London: K. Paul, Trench, Trubner \& Co., Ltd.; New York: A. A. Knopf).

Denton, B.E. (1991), The late second millennium BC in the Arab/Iranian Gulf, unpublished doctoral dissertation, Bryn Mawr College

Dickson, H.R.P. \& V.P. (1948), 'Thāj and other sites', Iraq, $\mathrm{X} / 1,1-8$
Eph'al, I. (1974), 'Arabs in Babylonia in the 8th century B.C.', JAOR, XCIV, 108-115

Eskoubi, K.M. (1985), 'Thāj excavations, second season 1404/1984', al-Atlal, IX, 41-52

Gazdar, M.S., Potts, D.T. \& Livingstone, A. (1984), 'Excavations at Thāj', al-Atlal, VIII, 55-108

G1assner, J.-J. (1984), 'Inscriptions cunéiformes de Failaka', in Failaka. Fouilles françaises 1983 (Lyon: Maison de l'Orient et de la Méditerranée Jean Pouilloux) pp. 31-50

al-Ghabban, A. (2011), 'Saudi Arabia reveals new historical finds dating back to 1 st century $\mathrm{BC}$ ' (http://www.eturbonews.com/22798/saudi-arabiareveals-new-historical-finds-dating-back-1 stcentur)

al-Ghamdi, S. (2013), Gerrha city and its foreign relations from the third century $B C$ until the end the first century AD: a historical-cultural study, unpublished doctoral dissertation, Umm al-Qura University

Golding, M. (1984), 'Artefacts from later pre-Islamic occupation in eastern Arabia', al-Atlal, VIII, 165172

Groom, N. (1982), 'Gerrha: a 'lost' Arabian city', alAtlal, VI, 97-108

Hamad bin Seray (1991), 'Jerhae: a lost Arabian city', University of the United Arab Emirates Historical Society, 1-63

al-Hamdān̄̄, al-Ḥasan ibn Aḥmad (1974), Sifat Jazīrat al-'Arab (Riyadh: Dār al-Yamāmah lil-Baḥth waal-Tarjamah wa-al-Nashr)

al-Hashash et al. (2002), 'The Archaeological works at the site of Thāj 1420AH /1999AD', al-Atlal, XVII, 17-21

al-Hashash et al. (2005), 'Report on the excavation of Thāj (1421 AH/2001 AD)', al-Atlal, XVIII, 35-54 
al-Hashash et al. (2006), 'Brief report on the Excavations at Thāj', al-Atlal, XIX, 15-19

Jamme, A. (1966), 'Sabaean and Hasaean inscriptions from Saudi Arabia', Studi semitici, no. 23, 65-82

Kuhrt, A. (1995), The ancient Near East c.3000-330 $B C E$ (London: Routledge)

Lapp, P.W. (1963), 'Observations on the pottery of Thâj', Bulletin of the American Schools of Oriental Research, no. 172 , pp. 20-22

Le Rider, G. (1965), Suse sous les Séleucides et les Parthes: les trouvailles monétaires et l'histoire de la ville. (Mémoires de la Délégation archéologique en Iran, vol. 38) (Paris: P. Geuthner)

Lorimer, J.G. (1908), Gazetteer of the Persian Gulf, Oman, and Central Arabia, vol. II (Calcutta: Supt. Government Printing)

Luckenbill, D.D. (1968), Ancient records of Assyria and Babylonia, vol. II: Historical records of Assyria from Sargon to the end (Chicago UP)

Mandaville, J.P. (1963), 'Thāj: a pre-Islamic site in northeastern Arabia', Bulletin of the American Schools of Oriental Research, CLXXII, 9-20

Mengin, F. (1823), Histoire de l'Egypte sous le gouvernement de Mohammed-Aly (Paris: A. Bertrand)

Moritz B., (1926), 'Die Nationalität der ArumuStämme in Südost-Babylonien', in C. Adler \& A. Ember (eds.), Oriental studies published in commemoration of the fortieth anniversary (18831923) of Paul Haupt as director of the Oriental Seminary of the Johns Hopkins University (Baltimore: Johns Hopkins Pr.) pp. 185-211

Mørkholm, O. (1960), 'Greek coins from Failaka', KUML (1960), 199-206

Mørkholm, O. (1972), 'A Hellenistic coin hoard from Bahrain’, KUML (1972), 183-202

Muḥammed ibn Ya'lā al-Ḍabbī (1963), Mufaḍdalīyāt, ed. A.M. Shakir \& 'A.S.M. Hārūn (Cairo: Dār al-
Ma'rif) (available online at: http://ia802600.us.archive.org/21/items/waqmfdliat waq/mfdliat.pdf)

Müller, W.W. (1978), 'Sabäische Felsinschriften von der jemenitischen Grenze zur Rub' al-Hāalì', Neue Ephemeris für semitische Epigraphik, III, 113-136

Müller, W.W. (1980), 'Some remarks on the Safaitic inscriptions', Proceeding of the Seminar for Arabian Studies, X, 67-74

Musil, A. (1927), Arabia Deserta: a topographical itinerary (New York: American Geographical Society)

Parr, P.J. (1964), 'Objects from Thāj in the British Museum', Bulletin of the American Schools of Oriental Research, CLXXVI, 20-28

Pelly, L. (1865), 'A visit to the Wahabee capital of central Arabia', Proceedings of the Royal Geographical Society of London, IX/6, 293-296

Pliny, the Elder (1968), Natural history, trans. H. Rackham (London: Heinemann)

Potts, D. et al. (1978), 'Comprehensive Archaeological Survey Program: preliminary report on the second phase of the Eastern Province survey 1397/1977', al-Atlal, II, 7-27

Potts, D. (1983), 'Thāj in the light of recent research', al-Atlal, VII, 86-101

Potts, D. (1984), 'Thāj and the location of Gerrha', Proceedings of the Seminar for Arabian Studies, XIV, 87-91

Potts, D. (1990), The Arabian Gulf in Antiquity. Vol. II: From Alexander the Great to the coming of Islam (Oxford: Clarendon Press)

Rachel (2011), An Archaeological Guide to Bahrain (Oxford: Archaeopress)

Robert, A. et al. (1977), 'Saudi Arabian archaeological reconnaissance -1976: Preliminary report on the first phase of a comprehensive archaeological survey program', al-Atlal, I, 20-40 
Robin, C. (1974), 'Monnaies provenant de l'Arabie du nord-est', Semitica, XXIV, 83-125 \& pl. I

Salles, J.-F. (1980), 'Monnaies d'Arabie orientale: éléments pour l'histoire des Emirats Arabes Unis à l'époque historique', Proceedings of the Seminar for Arabian Studies, X, 97-109

Strabo (1924), The Geography, trans. H.L. Jones. (Loeb classical library, vol. III.) (London: Heinemann)

von Wissmann, H. (1975), 'Die 'Hasäische' Schrift der Seleukidenzeit in Ostarabien', in Sammlung Eduard Glaser, Österreichische Akad. der Wissenschaften, phil. hist. Kl., Sitzungsberichte, XIII, 32-35
Winnett, F.V. (1946), 'A Himyaritic inscription from the Persian Gulf region', Bulletin of the American Schools of Oriental Research, CII, 5-7

Yāqūt al-Ḥamawī, S.D. (1955-7), Mu 'jam al-buldān, vol. I, (Beirut: Dār Șādir)

Zadok, R. (1981), 'Arabians in Mesopotamia during the late-Assyrian, Chaldean, Achaemenian and Hellenistic periods chiefly according to the cuneiform sources', Zeitschrift der Deutschen Morgenländischen Gesellschaft, CXXXI/1, 42-84

Zarins, J. et al. (1984), 'Excavations at Dhahran south the tumuli field (208-91), 1403 A.H. 1983. A preliminary report', al-Atlal, VIII, 25-54 


\section{ثاج في مسارها التاريخي والإنجازات السعودية فيها مروان غازي شعيب جامعة الملك عبدالعزبيز}

مستخلص يعتبر موقع ثاج الأثري واحداً من أهم المواقع الأثرية في شمال غرب الجزيرة العربية. غير أن البحوث والدراسات إلتي تتاولت هذا الموقع أظهرت العديد من التساؤلات إلتي تحناج إلي المزيد من البحث والتذقيق للوصول إلي أجوبة صحيحة لها. ومن الأمثلة على تللك التساؤلات: ما الآراء التي دارت حول النقوش والقطع النقدية التي عثر عيها في ثاج؟ ما النتائج التي توصلت إليها الحفريات والدراسات الأثرية الحديثة في ثاج؟ ما العلاقة بين ثاج والمدينة العربية المفقودة الجرهاء؟ هذه الدراسة تحاول الوصول إلى إجابات مقعنة، وصحيحة لهذه الأسئلة. وهي تناقش الدراسات السابقة المنشورة حول موضوع البحث. الكلمات المفتاحية: ثاج _ الجرهاء _ التاريخ القديم _ الأثار _ الحفريات _ النقوش الأحسائية. 